\title{
Faktor-Faktor Pendukung Keputusan Rujukan Pasien pada Fasilitas Kesehatan Tingkat Pertama (FKTP) dengan metode Analytical Hierrarchy Process (AHP)
}

\author{
Hilyah Magdalena $^{1^{*}}$, Hadi Santoso ${ }^{2}$, Dita Meliansari ${ }^{3}$ \\ ${ }^{123}$ Program Studi Sistem Informasi Institut Sains dan Bisnis Atma Luhur \\ *hilyah@atmaluhur.ac.id
}

\begin{abstract}
Pratama Bakti Timah Clinic is one of the First Level Health Facilities (FKTP) that provides health services to the community in the Pangkalpinang area and its surroundings. In these health service activities, when a patient requires special medical care in terms of medical services, medical personnel, medical support, outpatient services, and inpatient services, the patient will be referred to a higher health facility. Considering the various factors that cause patients to be referred and there are several hospitals that are referred to, this condition is a multi-criteria and multi-alternative condition. To overcome this, it is necessary to design a decision support system that will make it easier for medical administration service officers at the Primary Clinic. The decision support system is designed using the Analytical Hierarchy Process (AHP) method which is able to accommodate multicriteria and multi-alternative decision making. The results of data processing showed that the most important factor in the referral of FKTP patients at the Pratama Clinic was the outpatient service factor with a weight of $30.7 \%$, the second factor was medical services $24.4 \%$, the third factor was medical personel $17.5 \%$, the fourth factor was supporting medical services $15.9 \%$, and the last is inpatient services $11.4 \%$. While the first referral hospital is RSUD Ir. Soekarno with a weight of 31.1\%, then Depati Hamzah Hospital with a weight of 27.5\%, then Bakti Timah Hospital with 27.3\%, and Bakti Wara Hospital with 14.1\%.
\end{abstract}

Keywords: blended, mobile, web based learning

\begin{abstract}
Abstrak.
Klinik Pratama Bakti Timah adalah salah satu Fasilitas Kesehatan Tingkat Pertama (FKTP) yang menyediakan layanan kesehatan kepada masyarakat di wilayah Pangkalpinang dan sekitarnya. Dalam kegiatan layanan kesehatan tersebut, saat pasien membutuhkan perawatan medis khusus baik dari segi pelayanan medis, tenaga medis, penunjang medis, layanan rawat jalan, maupun layanan rawat inap, maka pasien akan dirujuk ke fasilitas kesehatan yang lebih tinggi. Menimbang beragamnya faktor yang menyebabkan pasien dapat dirujuk dan ada beberapa rumah sakit yang menjadi tujuan rujukan, maka kondisi ini adalah kondisi multikriteria dan multialternatif. Untuk mengatasi hal ini maka perlu di desain sistem pendukung keputusan yang akan mempermudah petugas layanan administrasi medis di Klinik Pratama. Sistem pendukung keputusan di desain dengan metode Analytical Hierarchy Process (AHP) yang mampu mengakomodir pengambilan keputusan dengan multikriteria dan multialternatif. Hasil pengolahan data menunjukkan bahwa faktor yang paling penting dalam rujukan pasien FKTP di Klinik Pratama adalah faktor layanan rawat jalan dengan bobot 30,7\%, faktor kedua adalah pelayanan medis $24,4 \%$, faktor ketiga tenaga medis $17,5 \%$, faktor keempat penunjang medis $15,9 \%$, dan terakhir adalah layanan rawat inap $11,4 \%$. Sedangkan rumah sakit rujukan pertama adalah RSUD Ir. Soekarno dengan bobot 31,1\%, lalu RSUD Depati Hamzah dengan bobot 27,5\%, kemudian RS Bakti Timah 27,3\%, dan RS Bakti Wara $14,1 \%$.
\end{abstract}

Kata kunci: blended, mobile, web based learning

\section{Pendahuluan}

\subsection{Sub Judul}

Layanan kesehatan bagi seluruh lapisan masyarakat dijamin oleh pemerintah dalam Undang-Undang Republik Indonesia Nomor
24 Tahun 2011 Tentang Badan Penyelenggara Jaminan Sosial. Pada UU No.24 tahun 2011 ini dijelaskan bahwa sistem jaminan sosial nasional merupakan program negara yang bertujuan memberikan kepastian 
perlindungan dan kesejahteraan sosial bagi seluruh rakyat[1].

Pada kondisi pandemi yang telah berlangsung hampir dua tahun ini, layanan kesehatan menjadi sangat penting. Layanan kesehatan yang termasuk dalam jaminan sosial nasional termaktub dalam layanan Badan Penyelenggara Jaminan Sosial yang selanjutnya disingkat BPJS adalah badan hukum yang dibentuk untuk menyelenggarakan program jaminan sosial. Fasilitas layanan kesehatan yang umumnya pertama kali diakses oleh masyarakat peserta BPJS adalah fasilitas kesehatan tingkat 1 (faskes tingkat 1). Faskes tingkat 1 ini adalah puskesmas, poliklinik, klinik pratama atau yang setara, prakter dokter, atau prakter dokter gigi[2].

Di Kota Pangkalpinag, salah satu faskes tingkat 1 yang menjadi tujuan masyarakat sekitar untuk mendapatkan layanan kesehatan adalah Klinik Pratama Pangkalpinang. Klinik Pratama Pangkalpinang adalah bagian dari PT. Rumah Sakit Bakti Timah Pangkalpinang, yang menaungi empat rumah sakit yang tersebar di beberapa kota, yaitu Rumah Sakit Bakti Timah Pangkalpinang, Rumah Sakit Medika Stania Sungailiat, Rumah Sakit Bakti Timah Muntok, dan Rumah Sakit Bakti Timah Karimun. Selain itu, PT Rumah Sakit BAkti Timah juga memiliki beberapa Klinik Pratama yang juga tersebar di beberapa kota yaitu Klinik Pratama Pangkalpinang, Klinik Pratama Jakarta, Klinik Pratama Prayun Kundur, Klinik Pratama Pangkalbalam, dan Klinik Pratama Manggar[3].

Dalam upaya melayani kebutuhan masyarakat di bidang kesehatan, Klinik Pratama Pangkalpinang sebagai Faskes 1, bisa saja menerima pasien yang membutuhkan layanan kesehatan yang lebih tinggi dari yang ada di faskes 1 atau membutuhkan layanan kesehatan spesialistik atau subspsesialistik. Jika menghadapi kondisi demikian, pasien akan dirujuk ke faskes lain baik itu yang setara atau yang berbeda tingkatannya. Pada buku panduan praktis sistem rujukan berjenjang diuraikan detil prosedur sistem rujukan layanan kesehatan yang mengatur rujukan sebagai pelimpahan tugas dan tanggung jawab layanan kesehatan[4].

Mengingat PT Rumah Sakit Bakti Timah memiliki jaringan rumah sakit, klinik pratama dan klinik rawat inap yang cukup banyak, maka pasien faskes tingkat 1 di Klinik Pratama Pangkalpinang, umumnya akan dirujuk ke Rumah Sakit Bakti Timah lainnya, namun tidak tertutup kemungkinan akan dirujuk ke Rumah Sakit lain yang ada di Pangkalpinang, seperti RSUD Ir. Soekarno, Rumah Sakit Bakti Wara, atau RSUD Depati Hamzah,

Kondisi pasien yang beragam dan kebutuhan layanan yang juga beragam membuat tenaga dokter yang bertugas di Faskes tingkat 1 Klinik Pratama Pangkalpinang, harus membuat keputusan rujukan pasien saat kebutuhan layanan kesehatan tidak bisa diberikan di Faskes 1. Untuk mempermudah membuat keputusan rujukan pasien, maka penelitian ini merancang sistem pendukung keputusan rujukan pasien berdasarkan kebutuhan layanan pasien di Faskes 1 Klinik Pratama Pangkalpinang.

Sistem pendukung keputusan ini akan dibangun dengan metode Analytical Hierarchy Process (AHP). Metode AHP dipilih karena menggunakan konsep mendukung pengambilan keputusan dengan multi kriteria dan multi alternatif[5].

Hal ini sesuai dengan kondisi pengambilan keputusan untuk menentukan rumah sakit rujukan dengan mempertimbangkan beberapa kriteria. AHP yang dikembangkan oleh TL.Saaty, adalah metode pengambilan keputusan yang secara matematis untuk menyusun keputusan secara hierarkis (untuk mengurangi kompleksitasnya) dan menunjukkan hubungan antara tujuan (kriteria) dam kemungkinan alternative[6].

Pentingnya sistem rujukan pada Fasilitas Kesehatan Tingkat Pertama dapat dilihat pada beberapa penelitian berikut ini. Pada Rumah Sakit Islam Sultan Agung Semarang yang mengusung model rumah sakit syariah, hasil penelitian menunjukkan bahwa pasien memilih layanan rawat inap di RS tersebut berdasarkan kualitas layanan kesehatannya, sedangkan harga, 
keterjangkauan lokasi, religiusitas tidak mempengaruhi keputusan pasien[7].

Proses sistem rujukan di Fasilitas Kesehatan Tingkat Pertama (FKTP) bagi peserta BPJS di Kabupaten Jepara, umumnya berkaitan dengan indikasi medis yang non spesialistik, bila diagnosa pasien diluar kompetensi FTKP, maka dirujuk ke Faskes tingkat lanjut secara berjenjang[8].

Di Puskesmas Sukasari Kabupaten Sumedang, sistem rujukan pasien BPJS dari FKTP ke FKTL menggunakan rujukan online. Penelitian ini menyimpulkan bahwa peserta BPJS cukup puas dengan sistem rujukan online. Tingkat kepuasan pasien ini berkaitan dengan meningkatnya pemahaman terhadap sistem rujukan berbasis online tersebut[9].

Penelitian serupa juga dilakukan di Puskesmas Neglasari Kota Tangerang, yang menganalisis pelaksanaan rujukan rawat jalan pada FTKP. Penelitian ini menyimpulkan bahwa pasien yang dirujuk rawat jalan umumnya karena menderita penyakit kronik dan mengalami komplikasi sehingga membutuhkan penanganan fasilitas kesehatan tingkat lanjut[10].

Penelitian yang menganalisis pelaksanaan rujukan rawat jalan di Puskesmas Pandanaran dan Puskesmas Gunungpati, menyimpulkan bahwa diagnosis dan klasifikasi diagnosis pasien yang dirujuk bervariasi dengan pemberi rujukan adalah dokter dan dokter gigi yang bertugas[11].

Berdasarkan analisa dari beberapa penelitian terdahulu yang mengambil tema sistem rujukan pasien pada Fasilititas Kesehatan Tingkat Pertama di berbagai kota dengan berbagai sudut pandang dan kebutuhan, maka penelitian ini fokus pada upaya mengembangkan sistem pendukung keputusan berbasis web yang analisa factor factor pendukung rujukan pasiennya akan dilakukan dengan metode Analytical Hierarchy Proses (AHP). Tujuan penelitian ini adalah menyediakan sistem yang mampu memberikan keputusan merujuk pasien FKTP khususnya pada Klinik Pratama Pangkalpinang dengan beberapa faktor yang umum ada di pasien FKTP Klinik Pratama. Dengan adanya sistem pendukung keputusan ini, maka proses pengajuan rujukan pasien bisa lebih cepat karena berbasis web.

\section{Metoda Penelitian}

Sistem pendukung keputusan awalnya didefinisikan sebagai sistem untuk mendukung manajerial pengambil keputusan dalam situasi keputusan semi terstruktur. SPK menjadi tambahan informasi dalam proses pengambilan keputusan dan memperluas kemampuan manajerial dalam mengambil keputusan, namun tidak menggantikan penilain manajer dalam mengambil keputusan. Sebuah SPK umumnya dibangun untuk mendukung solusi masalah tertentu atau untuk mengevaluasi suatu peluang. Dengan demikian, SPK adalah pendekatan (metodologi) untuk mendukung pengambilan keputusan yang interaktif, fleksibel, dan mudah beradaptasi. Akhirnya SPK dapat digunakan berbasis web untuk digunakan banyak orang di beberapa lokasi[12].

Salah satu metode dalam SPK adalah AHP. AHP adalah teori dan metodologi untuk pengukuran relatif dengan mengatahui alternatif terbaik. Lingkup akhir AHP adalah menggunakan perbandingan berpasangan antara alternatif sebagai input, untuk menghasilkan peringkat alternatif, sesuai dengan teori pengukuran alternatif. Oleh karena itulah AHP digunakan sebagai teknologi untuk mendukung pengambilan keputusan multi kriteria[13].

Dalam menggunakan AHP untuk memodelkan suatu masalah, seseorang membutuhkan hierarki atau jaringan struktur untuk mewakili masalah itu, serta perbandingan berpasangan untuk membangun hubungan di dalam struktur. Ada empat aksioma dalam AHP. Pertama adalah hubungan timbal balik, perbandingan elemen homogen, hierarki dan ketergantungan sistem dan nilai hasil dan ketergantungannya pada struktur dan ekstensinya[14].

Menurut Saaty, sebagai penemu metode AHP, untuk mendapatkan dunia yang lebih baik, maka salah satu caranya adalah dengan mengubah cara dunia membuat keputusan, yang semula menggunakan kata - kata menjadi menggunakan angka. Maka keputusan berkaitan dengan mengukur kepentingan, preferensi, dan kemungkinan 
pengaruh. Seorang pengambil keputusan membuat perbandingan berpasangan untuk menilai berapa banyak satu elemen mendominasi yang lain sehubungan dengan properti tertentu; artinya seberapa penting atau lebih disukai suatu elemen dibanding dengan lainnya[15].

Berdasarkan konsep 7 pilar AHP, maka skala perbandingan berpasangan antar elemen dalam hirarki diberi nilai dengan skala fundamental AHP berikut :

Table 1. Skala Fundamental Bilangan Mutlak[16]

\begin{tabular}{ll}
\hline Level & \multicolumn{1}{c}{ Arti } \\
\hline 1 & $\begin{array}{l}\text { Kedua elemen sama pentingnya,kedua elemen } \\
\text { mempunyai pengaruh yang sama besar }\end{array}$ \\
& $\begin{array}{l}\text { Elemen yang satu sedikit lebih penting } \\
\text { daripada elemen yang lainnya,pengalaman } \\
\text { dan penilaian sedikit menyokong satu elemen } \\
\text { dibanding elemen yang lainnya. }\end{array}$ \\
& $\begin{array}{l}\text { Elemen yang satu lebih penting daripada yang } \\
\text { lainnnya,pengalaman dan penilaian sangat }\end{array}$ \\
& kuat menyokong satu elemen dibandingkan \\
elemen yang lainnya & Satu elemen jelas lebih mutlak penting dari \\
pada elemen lainnya,satu elemen yang kuat \\
dikosong dan dominan terlihat dalam praktek \\
Satu elemen mutlak penting daripada elemen \\
lainnya. Bukti yang mendukung elemen yang \\
satu terhadap elemen yang lain memiliki \\
tingkat penegasan tertinggi yang mungkin \\
menguatkan. \\
Nilai-nilai antara dua nilai pertimbangan- \\
perrtimbangan yang berdekatan. Nilai ini \\
diberikan bila ada dua kompromi diantara 2 \\
pilihan.
\end{tabular}

Sebagai metode pendukung keputusan populer dan luwes dalam mengakomodir kondisi multi criteria dan multi alternative, AHP dapat digunakan untuk mendukung pengambilan keputusan diberbagai bidang, termasuk bidang kesehatan

Pada metode AHP, ada beberapa tahap pengolahan data seperti tampak pada gambar 1.

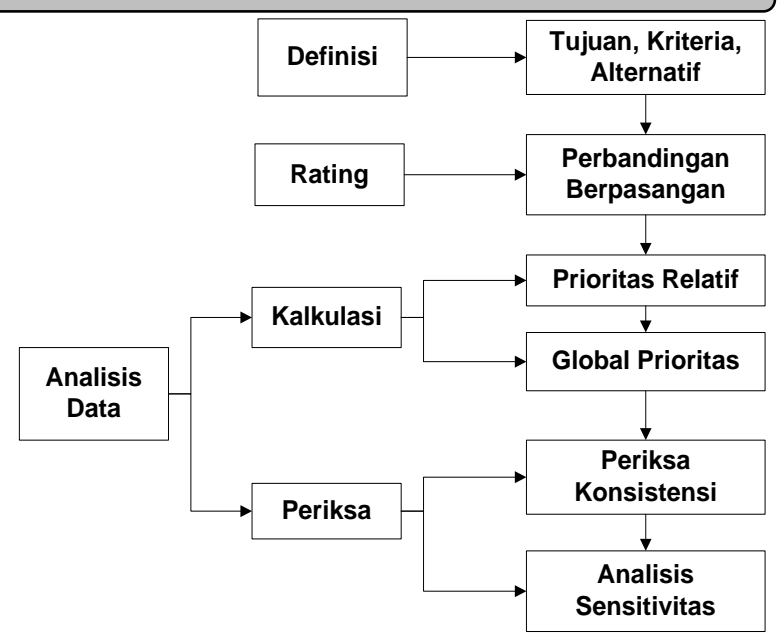

Gambar 1. Langkah - Langkah Metode AHP

Gambar 2 berikut ini Hirarki Faktor Faktor Pendukung Keputusan untuk Pemberian Rujukan Pasien FKTP ke rumah sakit di Pangkalpinang.

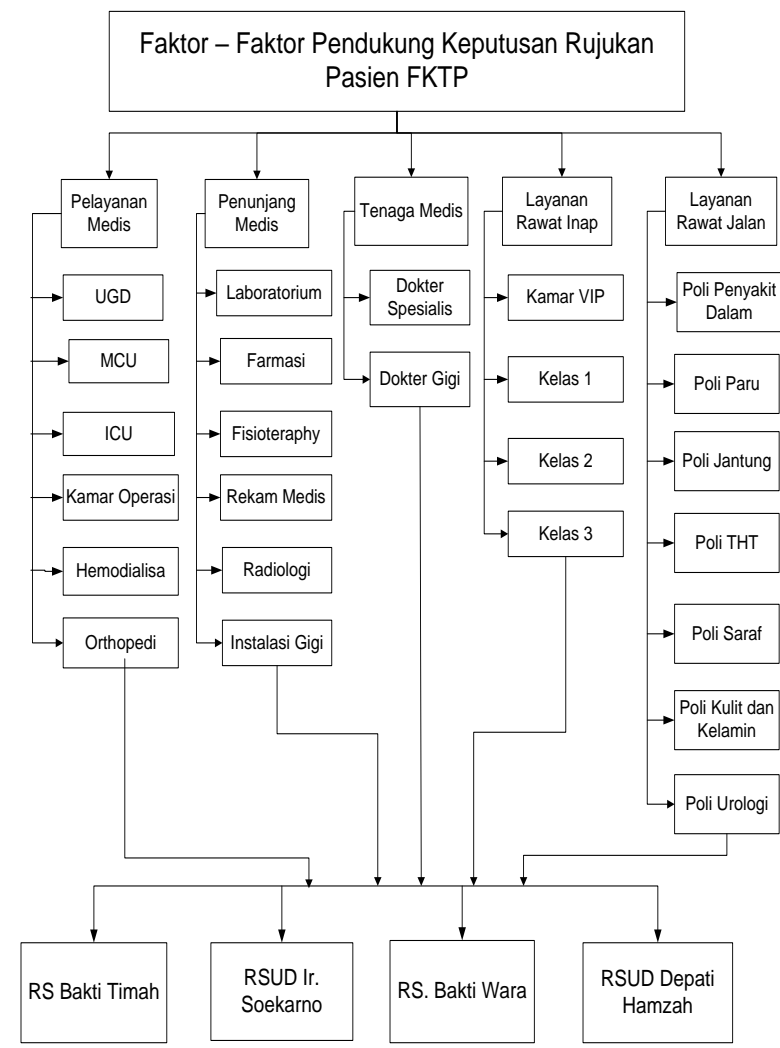

Gambar 1. Struktur Hierarchy Analytic

Setelah hirarki analitik terbentuk, maka tahap selanjutnya adalah menyusun kuesioner sesuai dengan struktur hirarki analitik. Metode AHP membutuhkan masukan berupa penilaian para pakar (expert jugdement). Dalam penelitian ini, penilaian para pakar 
diberikan oleh tiga orang yaitu Kepala Klinik, satu dokter umum, dan satu dokter gigi.

Pengolahan data untuk menghitung prioritas relatif tiap responden dan gabungan prioritas relatif sebagai global prioritas dilakukan dengan perangkat lunak Expert Choice. Expert Choice adalah Perangkat lunak Expert Choice adalah alat pendukung keputusan multi-tujuan berdasarkan Analytic Hierarchy Process (AHP). Expert Choice memiliki metode unik dalam menggunakan perbandingan berpasangan untuk mendapatkan prioritas yang mencerminkan persepsi dan nilai secara lebih akurat. Berdasarkan masukan penilaian pakar, Expert Choice dapat mensintesis atau menggabungkan prioritas untuk mendapatkan prioritas keseluruhan dari alternatif [17].

\section{Hasil Penelitian}

Pada tahap analisis data, terdapat dua tahap yang akan dilakukan yaitu tahap kalkulasi dan tahap periksa. Tahap kalkulasi akan terbagi menjadi dua tahap yaitu tahap prioritas relatif dan global prioritas. Sedangkan tahap periksa terdiri dari dua tahap yaitu periksa konsistensi dan analisis sensitivitas.

\subsection{Kalkulasi Prioritas Relatif}

Proses perbandingan berpasangan dilakukan bertahap, yaitu mulai dari menghitung perbandingan berpasangan responden satu sampai tiga yang menghasilkan prioritas relatif, kemudian semua hasil prioritas relatif digabungkan menjadi global prioritas yang menjadi hasil pengolahan data. Gambar $2-7$ berikut ini menunjukkan hasil kalkulasi prioritas relatif salah satu responden.

Model Name. Faklor - Fàkar Pendukung Keputusan Rujukan Pasien FKTP

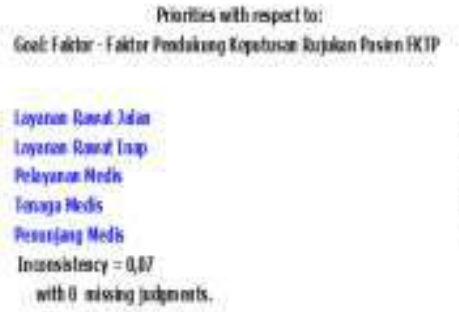

Gambar 2. Kalkukasi Prioritas Relatif Tujuan

Model Name Faitor - Faktox Penddhng Keputusan Rujukan Pasien FKTP
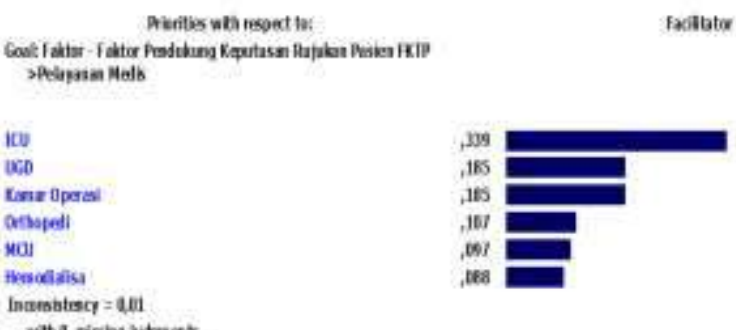

with tising ybaes.

Gambar 3. Kalkukasi Prioritas Relatif Kriteria Pelayanan Medis

Model Name Faltor - Fahłor Pendukung Keputusan Rajukan Pasien FKTP
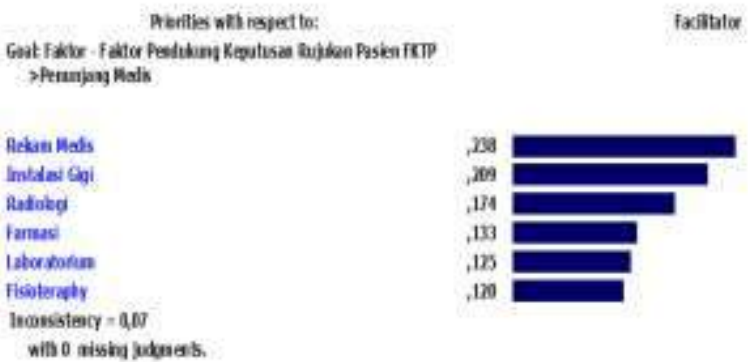

Gambar 4. Kalkukasi Prioritas Relatif Kriteria Penunjang Medis

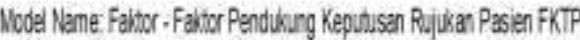

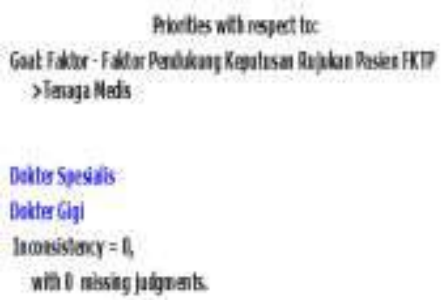

Gambar 5 Kalkukasi Prioritas Relatif Kriteria Tenaga Medis 


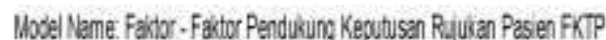

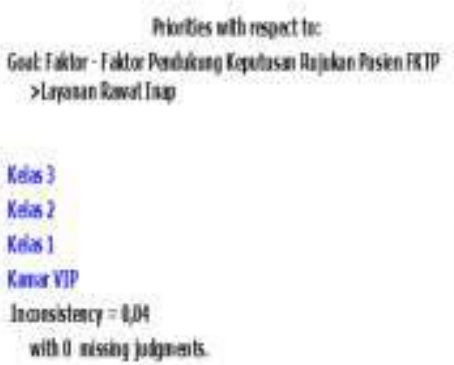

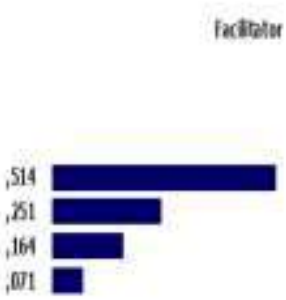

Gambar 6. Kalkukasi Prioritas Relatif Kriteria Layanan Rawat Inap

Wojel Nama Faitor - Fashor Pendikurg Kepulisan Rujukin Pasien FKTP

\begin{tabular}{|c|}
\hline 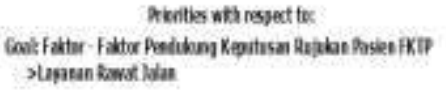 \\
\hline Aal Arak \\
\hline Dilat \\
\hline Aal Manjakt Dosan \\
\hline Bi Pan \\
\hline Aal orthapeli \\
\hline PIIII \\
\hline pal sact: \\
\hline Bil lating \\
\hline 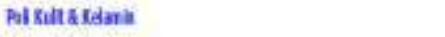 \\
\hline Pal theogi \\
\hline Innesibtesc $=0106$ \\
\hline
\end{tabular}

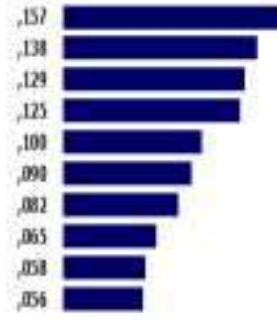

Gambar 7. Kalkukasi Prioritas Relatif Kriteria Layanan Rawat Jalan

\subsection{Kalkulasi Global Prioritas}

Setelah semua responden dihitung prioritas relatif-nya, maka tahap selanjutnya adalah menggabungkan semua prioritas relatif sehingga menjadi global prioritas. Gambar $8-12$ berikut ini adalah hasil kalkulasi global prioritas yang disajikan dalam bentuk struktur pohon yang menampilkan persentasi kriteria dan alternatif-nya
Treevew

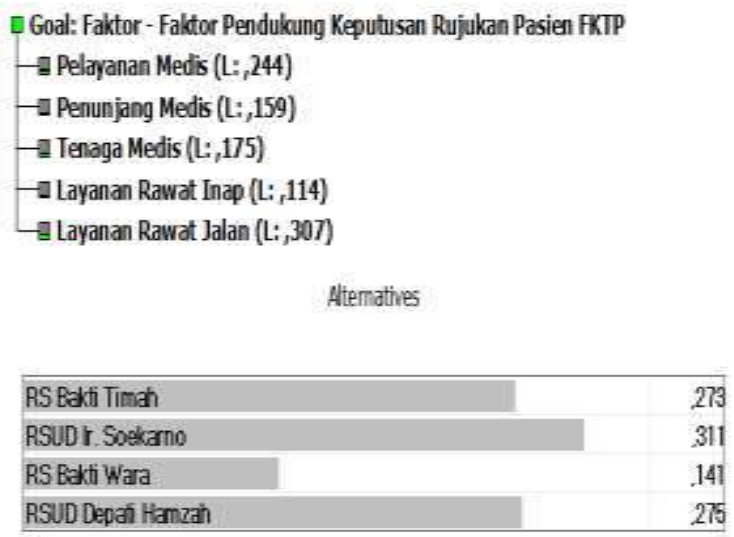

Gambar 8. Kalkulasi Global Prioritas untuk Tujuan

Selanjutnya adalah hasil pengolahan data gabungan untuk kriteria Pelayanan Medis,

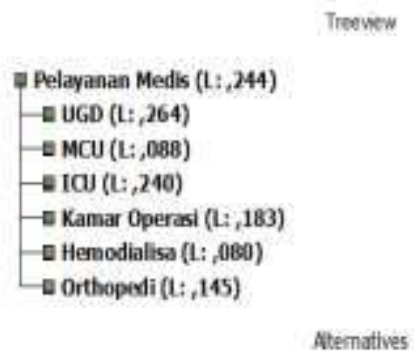

\begin{tabular}{|c|c|}
\hline BS Bakt Timah. & 302 \\
\hline RSUDE Soekamo & 293 \\
\hline RSS Bakt Wara & 196 \\
\hline RSUD Digat Hamzan & 268 \\
\hline
\end{tabular}

Gambar 9. Kalkulasi Global Prioritas untuk Kriteria Pelayanan Medis

Kemudian, pada gambar 10 berikut adalah hasil pengolahan data gabungan untuk kriteria Penunjang Medis

$$
\text { Treenew }
$$

$$
\begin{aligned}
& \text { ص Penunjang Medis }(L:, 159) \\
& \text { - Laboratorium }(\mathrm{L} ; \text {, 206) } \\
& \text { - Farmasi (L: 124) } \\
& \text { - Fisioteraphy }(L:, 105) \\
& \rightarrow \text { Rekam Medis }(\mathrm{L} ;, 115) \\
& \text { \Radiologi (L:, 232) } \\
& \text { - Instalasi Gini (L: ,218) }
\end{aligned}
$$

\section{Ahernatives}

\begin{tabular}{lr}
\hline RS Baki Timah & 262 \\
RSUD r. Soekamo & 310 \\
RS Baki Wara & 148 \\
\hline RSUD Depaji Hamzah & 280 \\
\hline
\end{tabular}

Gambar 10. Kalkulasi Global Prioritas untuk Kriteria Penunjang Medis 
Hasil berikutnya pada gambar 11 adalah global prioritas untuk kriteria tenaga medis

\section{Treevew}

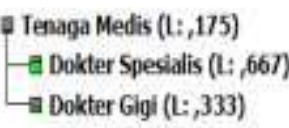

Nitematives

\begin{tabular}{|c|c|}
\hline AS Baks Timah & 254 \\
\hline RSUD r Soekamo & 338 \\
\hline RS Baka Wara & .135 \\
\hline RSUD Deadi Hamzdh & 277 \\
\hline
\end{tabular}

Gambar 11. Kalkulasi Global Prioritas untuk Kriteria Tenaga Medis

Kemudian pada gambar 12 dan 13 berikut menampilkan hasil global prioritas untuk kriteria Layanan Rawat Inap dan Layanan Rawat Jalan,
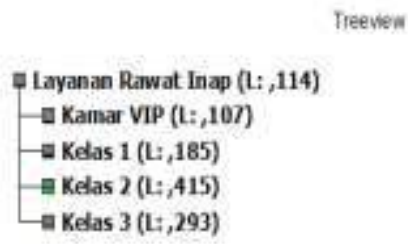

Nternatives

\begin{tabular}{|c|c|}
\hline RS Baki Timah & 234 \\
\hline RSUD r. Soekamo & 353 \\
\hline RSBakti Wara & .148 \\
\hline RSUD Depat Hamad & 288 \\
\hline
\end{tabular}

Gambar 12. Kalkulasi Global Prioritas untuk Kriteria Layanan Rawat Inap Treevew

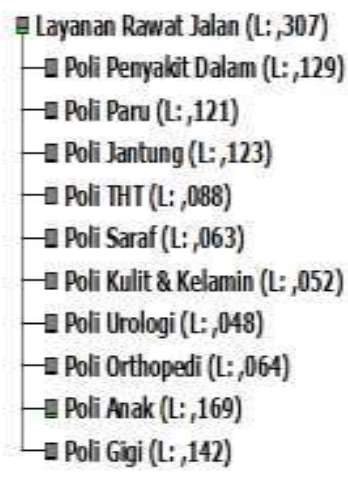

Aternatives

\begin{tabular}{|ll|}
\hline RS Bakti Timah & 279 \\
\hline RSUD r. Soekamo & $3 \% 6$ \\
\hline RS Bakti Wara & 143 \\
\hline RSUD Depali Hamzah & 272 \\
\hline
\end{tabular}

Gambar 13. Kalkulasi Global Prioritas untuk Kriteria Layanan Rawat Jalan

\subsection{Periksa Konsistensi}

Setelah mendapatkan hasil prioritas relative tiap responden dan global prioritas sebagai gabungan semua prioritas relative yang disajikan dalam bentuk grafik sebagai hasil olahan data dengan bantuan perangkat lunak Expert Choice. Maka tahap selanjutnya sdalah memeriksa tingkat inkonsistensi.

Tabel 2. Inkonsistensi Rasio (IR)

\begin{tabular}{|c|c|c|}
\hline No & Prioritas Kriteria & IR \\
\hline 1. & $\begin{array}{l}\text { Faktor - Faktor Pendukung } \\
\text { Keputusan Rujukan Pasien FKTP }\end{array}$ & 0.04 \\
\hline 2. & $\begin{array}{l}\text { Faktor - Faktor Pendukung } \\
\text { Keputusan Rujukan Pasien FKTP } \\
\text { untuk Kriteria Pelayanan Medis }\end{array}$ & 0.04 \\
\hline 3. & $\begin{array}{l}\text { Faktor - Faktor Pendukung } \\
\text { Keputusan Rujukan Pasien FKTP } \\
\text { untuk Kriteria Level } 1 \rightarrow \text { Pelayanan } \\
\text { Medis, Sub Kriteria Level } 2 \rightarrow \\
\text { UGD }\end{array}$ & 0,00 \\
\hline 4. & $\begin{array}{l}\text { Faktor - Faktor Pendukung } \\
\text { Keputusan Rujukan Pasien FKTP } \\
\text { untuk Kriteria Level } 1 \rightarrow \text { Pelayanan } \\
\text { Medis, Sub Kriteria Level } 2 \rightarrow \\
\text { MCU }\end{array}$ & 0,02 \\
\hline 5. & $\begin{array}{l}\text { Faktor - Faktor Pendukung } \\
\text { Keputusan Rujukan Pasien FKTP } \\
\text { untuk Kriteria Level } 1 \rightarrow \text { Pelayanan } \\
\text { Medis, Sub Kriteria Level } 2 \rightarrow \\
\text { ICU }\end{array}$ & 0,004 \\
\hline 6. & $\begin{array}{l}\text { Faktor - Faktor Pendukung } \\
\text { Keputusan Rujukan Pasien FKTP } \\
\text { untuk Kriteria Level } 1 \rightarrow \text { Pelayanan } \\
\text { Medis, Sub Kriteria Level } 2 \rightarrow \\
\text { Kamar Operasi }\end{array}$ & 0,004 \\
\hline 7. & $\begin{array}{l}\text { Faktor - Faktor Pendukung } \\
\text { Keputusan Rujukan Pasien FKTP } \\
\text { untuk Kriteria Level } 1 \rightarrow \text { Pelayanan } \\
\text { Medis, Sub Kriteria Level } 2 \rightarrow \\
\text { Hemodialisa }\end{array}$ & 0,004 \\
\hline 8. & $\begin{array}{l}\text { Faktor - Faktor Pendukung } \\
\text { Keputusan Rujukan Pasien FKTP } \\
\text { untuk Kriteria Level } 1 \rightarrow \text { Pelayanan } \\
\text { Medis, Sub Kriteria Level } 2 \rightarrow \\
\text { Orthopedi }\end{array}$ & 0,02 \\
\hline 9. & $\begin{array}{l}\text { Faktor - Faktor Pendukung } \\
\text { Keputusan Rujukan Pasien FKTP } \\
\text { untuk Kriteria Penunjang Medis }\end{array}$ & 0,03 \\
\hline 10. & $\begin{array}{l}\text { Faktor - Faktor Pendukung } \\
\text { Keputusan Rujukan Pasien FKTP } \\
\text { untuk Kriteria Level } 1 \rightarrow \text { Penunjang } \\
\text { Medis, Sub Kriteria Level } 2 \rightarrow \\
\text { Laboratorium }\end{array}$ & 0,005 \\
\hline 11. & $\begin{array}{l}\text { Faktor - Faktor Pendukung } \\
\text { Keputusan Rujukan Pasien FKTP } \\
\text { untuk Kriteria Level } 1 \rightarrow \text { Penunjang } \\
\text { Medis, Sub Kriteria Level } 2 \rightarrow \\
\text { Farmasi }\end{array}$ & 0,02 \\
\hline 12. & $\begin{array}{l}\text { Faktor - Faktor Pendukung } \\
\text { Keputusan Rujukan Pasien FKTP } \\
\text { untuk Kriteria Level } 1 \rightarrow \text { Penunjang } \\
\text { Medis, Sub Kriteria Level } 2 \rightarrow \\
\text { Fisioteraphy }\end{array}$ & 0,00097 \\
\hline 13. & $\begin{array}{l}\text { Faktor - Faktor Pendukung } \\
\text { Keputusan Rujukan Pasien FKTP }\end{array}$ & 0,0076 \\
\hline
\end{tabular}


untuk Kriteria Level $1 \rightarrow$ Penunjang

Medis, Sub Kriteria Level $2 \rightarrow$

Rekam Medis

14. Faktor - Faktor Pendukung

Keputusan Rujukan Pasien FKTP untuk Kriteria Level $1 \rightarrow$ Penunjang

Medis, Sub Kriteria Level $2 \rightarrow$

Radiologi

15. Faktor - Faktor Pendukung

Keputusan Rujukan Pasien FKTP

untuk Kriteria Level $1 \rightarrow$ Penunjang

Medis, Sub Kriteria Level $2 \rightarrow$

Instalasi Gigi

16. Faktor - Faktor Pendukung

Keputusan Rujukan Pasien FKTP

untuk Kriteria Tenaga Medis

17. Faktor-Faktor Pendukung

Keputusan Rujukan Pasien FKTP

untuk Kriteria Level $1 \rightarrow$ Tenaga

Medis, Sub Kriteria Level $2 \rightarrow$

Dokter Spesialis

18. Faktor - Faktor Pendukung

Keputusan Rujukan Pasien FKTP

untuk Kriteria Level $1 \rightarrow$ Tenaga

Medis, Sub Kriteria Level $2 \rightarrow$

Dokter Gigi

19. Faktor - Faktor Pendukung

Keputusan Rujukan Pasien FKTP

untuk Kriteria Layanan Rawat Inap

20. Faktor - Faktor Pendukung

Keputusan Rujukan Pasien FKTP

untuk Kriteria Level $1 \rightarrow$ Layanan

Rawat Inap, Sub Kriteria Level 2

$\rightarrow$ Kamar VIP

21. Faktor - Faktor Pendukung

Keputusan Rujukan Pasien FKTP

untuk Kriteria Level $1 \rightarrow$ Layanan

Rawat Inap, Sub Kriteria Level 2

$\rightarrow$ Kelas 1

22. Faktor - Faktor Pendukung

Keputusan Rujukan Pasien FKTP

untuk Kriteria Level $1 \rightarrow$ Layanan

Rawat Inap, Sub Kriteria Level 2

$\rightarrow$ Kelas 2

23. Faktor - Faktor Pendukung

Keputusan Rujukan Pasien FKTP

untuk Kriteria Level $1 \rightarrow$ Layanan

Rawat Inap, Sub Kriteria Level 2

$\rightarrow$ Kelas 3

24. Faktor - Faktor Pendukung

Keputusan Rujukan Pasien FKTP

untuk Kriteria Layanan Rawat Jalan

25. Faktor - Faktor Pendukung

Keputusan Rujukan Pasien FKTP

untuk Kriteria Level $1 \rightarrow$ Layanan

Rawat Jalan, Sub Kriteria Level 2

$\rightarrow$ Poli Penyakit Dalam

26. Faktor - Faktor Pendukung

Keputusan Rujukan Pasien FKTP

untuk Kriteria Level $1 \rightarrow$ Layanan

Rawat Jalan, Sub Kriteria Level 2

$\rightarrow$ Poli Paru

27. Faktor - Faktor Pendukung

Keputusan Rujukan Pasien FKTP

untuk Kriteria Level $1 \rightarrow$ Layanan

Rawat Jalan, Sub Kriteria Level 2

$\rightarrow$ Poli Jantung

28. Faktor - Faktor Pendukung

Keputusan Rujukan Pasien FKTP

0.00

0,02

0,01 untuk Kriteria Level $1 \rightarrow$ Layanan

Rawat Jalan, Sub Kriteria Level 2

$\rightarrow$ Poli THT

29. Faktor - Faktor Pendukung

Keputusan Rujukan Pasien FKTP untuk Kriteria Level $1 \rightarrow$ Layanan

Rawat Jalan, Sub Kriteria Level 2

$\rightarrow$ Poli Saraf

0,00567

30. Faktor - Faktor Pendukung

Keputusan Rujukan Pasien FKTP untuk Kriteria Level $1 \rightarrow$ Layanan

Rawat Jalan, Sub Kriteria Level 2

$\rightarrow$ Poli Kulit Kelamin

31. Faktor - Faktor Pendukung

Keputusan Rujukan Pasien FKTP

untuk Kriteria Level $1 \rightarrow$ Layanan

0,0076

Rawat Jalan, Sub Kriteria Level 2

$\rightarrow$ Poli Urologi

32. Faktor - Faktor Pendukung

Keputusan Rujukan Pasien FKTP

untuk Kriteria Level $1 \rightarrow$ Layanan

Rawat Jalan, Sub Kriteria Level 2

$\rightarrow$ Poli Orthopedi

33. Faktor - Faktor Pendukung

Keputusan Rujukan Pasien FKTP

untuk Kriteria Level $1 \rightarrow$ Layanan

Rawat Jalan, Sub Kriteria Level 2

$\rightarrow$ Poli Anak

34. Faktor - Faktor Pendukung

0,00567

0,00

0,00901

Keputusan Rujukan Pasien FKTP untuk Kriteria Level $1 \rightarrow$ Layanan Rawat Jalan, Sub Kriteria Level 2 $\rightarrow$ Poli Gigi

Hasil periksa inkonsistensi rasio semua kriteria, sub kriteria mempunyai nilai dibawah $10 \%$ atau 0,1 yang mengindikasikan bahwa hasil pengukuran dianggap sahih dan konsisten

\subsection{Analisis Sensitivitas}

0,00567 Hasil analisis sensitivitas menunjukkan alternatif apa yang tinggi nilainya dibandingkan dengan alternatif lainnya. Hasil analisis ini sekaligus menunjukkan alternatif terpilih yang dilengkapi dengan persentasenya.

\section{Nodel Nane: Fahtor - Faktor Pendukung Keputusan Rujukan Pasen FKTP}

\section{Sinthesis Qumman}

0,00567
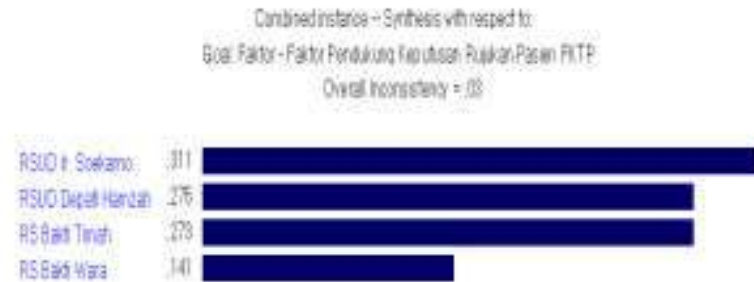

Gambar 14. Synthesis Summary 
Berdasarkan hasil analisis sensitivitas, maka rumah sakit rujukan yang paling tinggi nilainya adalah RSUD Ir. Soekarno dengan bobot $31,1 \%$, posisi kedua adalah RSUD Depati Hamzah dengan bobot 27,5\%, posisi ketiga RS Bakti Timah dengan bobot 27,3\% dan terakhir adalah RS Bakti Wara dengan bobot $14,1 \%$.

Berikut ini adalah tampilan Dynamic Sensitivity yang menampilkan berdampingan antara kriteria level 1 dan alternatif.

\section{Dynamic Sensitivity for nodes below: Goal: Faktor - Faktor Pendukung} Keputusan Rujukan Pasien FKTP

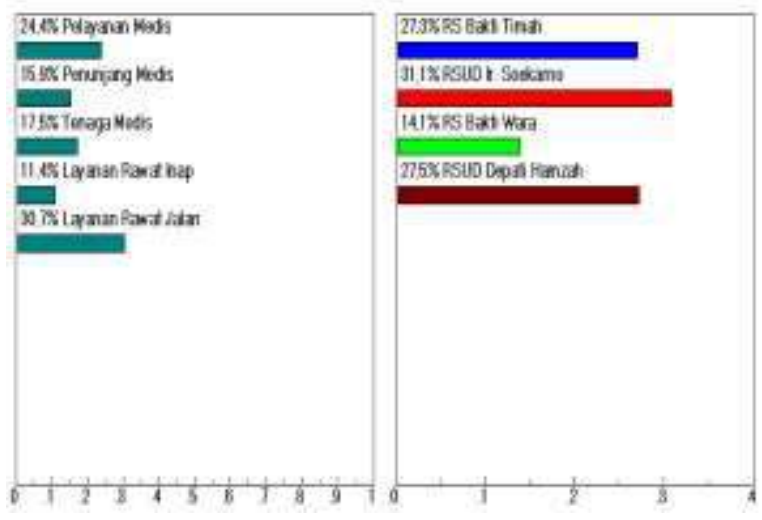

Gambar 15 . Dymanic Sesnsitivity

Pada tampilan Dynamic Sensitivity juga terlihat bahwa layanan rawat jalan adalah faktor paling penting dengan bobot 30,7\%, posisi kedua adalah faktor pelayanan medis dengan $24,4 \%$, kemudian posisi ketiga adalah faktor tenaga medis dengan bobot $17,5 \%$, selanjutnya adalah faktor penunjang medis dengan bobot $15,9 \%$, dan terakhir adalah faktor layanan rawat inap dengan bobot $11,4 \%$.

\section{Kesimpulan}

Kebutuhan dan kemampuan menghasilkan keputusan yang tepat dan cepat saat merujuk pasien di Fasilitas Kesehatan Tingkat Pertama (FKTP) Klinik Pratama Bakti Timah mendorong dirancangnya sistem pendukung keputusan. Sistem pendukung keputusan ini dianalisis dengan metode Analytical Hierarchy Process menimbang kondisi merujuk pasien melibatkan beberapa faktor dan kemungkinan memilih satu dari beberapa alternatif rumah sakit. Faktor rawat jalan sebagai faktor dengan bobot tertinggi menunjukkan bahwa sebagian besar pasien yang dirujuk dari FKTP Klinik Pratama adalah pasien rawat jalan.

\section{Saran}

Diperlukan penelitian lebih lanjut yang mampu mengembangkan sistem berbasis berbasis web, sehingga pasien dapat dibantu untuk mendapatkan fasilitas dan rumah sakit rujukan yang sesuai dengan kondisinya. Analisis faktor - faktor pendukung keputusan rujukan pasien ini dapat dikembangkan jika ada kondisi khusus atau mendesak.

\section{Daftar Pustaka}

[1] Menteri Hukum dan HAM RI, UU RI No. 24 TAHUN 2011 Tentang Badan Penyelenggara Jaminan Sosial. 2011.

[2] Rizqia Khoirunisa, "Arti Faskes tingkat 1 pada kartu KIS BPJS Kesehatan," 2020. http://www.pasienbpjs.com/2020/01/a rti-faskes-tingkat-1-kis-bpjs.html.

[3] "Klinik Pratama Pangkalpinang." https://www.baktitimah.co.id/klinikpratama-pangkalpinang/.

[4] Direktur Utama BPJS Kesehatan, "Sistem Rujukan Berjenjang," 2014.

[5] N. F. Aziz, S. Sorooshian, and F. Mahmud, "MCDM-AHP method in decision makings," ARPN J. Eng. Appl. Sci., vol. 11, no. 11, pp. 72177220, 2016.

[6] E. M. M. Pereyra-Rojas, Practical Decision Making An Introduction to the Analytic HierarchyProcess (AHP) Using Super Decisions V2, no. 9. 2018.

[7] Z. S. Rochmiati, chriswardhani suryawati, "Faktor - Faktor yang Mempengaruhi Keputusan Pilihan Pasien Rawat Inap di Rumah Sakit Syariah," J. Kesehat. Masyaraka, vol. 8, no. 2, pp. 152-164, 2021.

[8] I. Indrianingrum and I. Puspitasari, "Evaluasi Proses Sistem Rujukan Badan Penyelenggara Jaminan Kesehatan Sosial (Bpjs) Kesehatan Di Fasilitas Kesehatan Tingkat Pertama (Fktp) Kabupaten Jepara," J. Ilmu Keperawatan dan Kebidanan, vol. 12, 
no. 1, p. 78, 2021, doi: 10.26751/jikk.v12i1.930.

[9] Y. Muchsam, F. Mareta, I. Kesehatan, and B. Indonesia, "Analisis Pengaruh Kepahaman Sistem Rujukan Online Peserta BPJS Terhadap Kepuasan Pelayanan BPJS," Semin. Nas. Inform. Medis, vol. 5, pp. 34-39, 2019.

[10] E. Y. F. Mutia Rizqa Firdiah, Ayun Sriatmi, "Analisis Pelaksanaan Rujukan Rawat Jalan Tingkat Pertama Pada Peserta Badan Penyelenggara Jaminan Sosial Kesehatan (Studi Kasus Di Puskesmas Neglasari Kota Tangerang)," J. Kesehat. Masy., vol. 5, no. 3, pp. 19-25, 2017.

[11] L. S. Umami, B. P. Soeharto, and D. R. Wulandari, "Analisis Pelaksanaan Rujukan Rawat Jalan Tingkat Pertama Peserta Bpjs Kesehatan Di Puskesmas," Diponegoro Med. J. (Jurnal Kedokt. Diponegoro), vol. 6, no. 2, pp. 758-771, 2017.

[12] E. Turban, J. Aronson, and T. Llang, Decision Support Systems and Intelligent Systems, Seventh ed. Prentice - Hall, 2003.

[13] M. Brunelli, Introduction to the
Analytic Hierarchy Process. 2015.

[14] F. S. Hillier, C. C. Price, and S. F. Austin, Models, Methods, Concepts \& Applications of the Analytic Hierarchy Process, Second Edi., vol. 175. 2015.

[15] T. L. Saaty, "Better world through better decision making," Proc. Int. Symp. Anal. Hierarchy Process 2013, pp. 1-9, 2013, [Online]. Available: http://www.isahp.org/uploads/1.pdf.

[16] T. L. Saaty, "Decision making with the analytic hierarchy process," Int. $J$. Serv. Sci., vol. 1, no. 1, p. 83, 2008, doi: 10.1504/IJSSCI.2008.017590.

[17] M. B. Barfod, "Graphical and technical options in Expert Choice for group decision making," p. 35, 2014, [Online]. Available:

http://orbit.dtu.dk/files/104238680/DT U_Transport_Compendium_Part_3_G roup_decision_making_.pdf. 